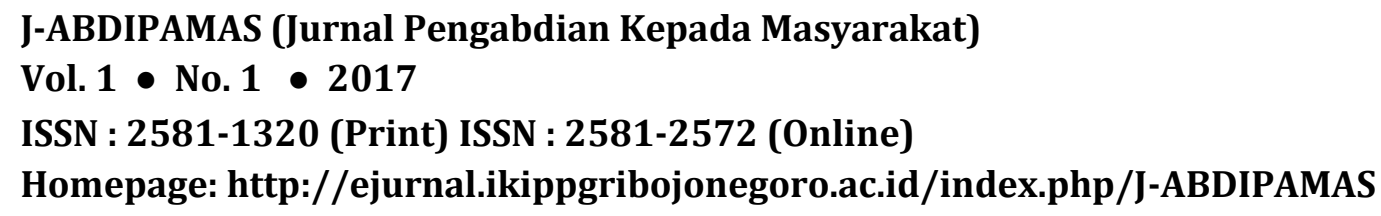

ISSN : 2581-1320 (Print) ISSN : 2581-2572 (Online)

Homepage: http://ejurnal.ikippgribojonegoro.ac.id/index.php/J-ABDIPAMAS

\title{
SISTEM PENANGGULANGAN TINDAKAN KEKERASAN OLEH WALI SISWA TERHADAP PENDIDIK SMK NEGERI 2 MAKASSAR
}

\author{
Aan Aswari ${ }^{1}$, Salim Basalamah², Amar Bachti ${ }^{3}$, Muh. Rinaldy Bima ${ }^{4}$ \\ 1Universitas Muslim Indonesia. Email: aanaswari@umi.ac.id \\ 2Universitas Muslim Indonesia. Email: - \\ 35MK Negeri 2 Makassar. Email: bachtiamar@gmail.com \\ 4Universitas Muslim Indonesia. Email: -
}

\begin{abstract}
ABSTRAK
Situasi sekolah setingkat SMU/Kejuruan telah mengikuti perkembangan model sekolah moderen dalam rangka menyesuaikan eksistensinya diera teknologi. Sinkronisasi diyakini dapat meningkatkan keunggulan, diantaranya dalam bentuk pergaulan lintas batas kewilayahan dan membentuk suasana kompetitif antar sekolah. Hal itu menumbuhkan berbagai subsistem baru dalam peningkatan mutu sekolah, namun sesungguhnya menimbulkan sebuah tambahan tantangan dalam menjalankan subsistem dalam sekolah tersebut, sehingga perlu pendekatan hukum sebagai solusi terhadap potensi konflik. Metode pelaksanaan dalam pengabdian ini menggunakan tehnik ceramah/sosialisasi agar terciptanya sebuah kesadaran hukum bagi siswa, guru dan wali siswa demi mencegah permasalahan hukum. Sosialisasi dan penerapan simbol hukum agar transfer ilmu pengetahuan kepada unsur dalam sekolah tidak bias setelah pengabdian pada siswa telah selesai. Pengabdian ini menekankan pada 4 poin penting, diantaranya: (1) Pendekatan Keagamaan, (2) Pengembangan Moral \& Etika siswa, (3) Pentingnya Kedisiplinan, dan (4) Menanamkan Kesadaran Hukum, yang diyakini mampu membantu menjaga proses sekolah meraih tujuan-tujuannya setiap saat. Akhirnya, keseluruh poin penting ini menjadi acuan untuk dilaksanakannya berbagai kegiatan kongkrit dalam lingkugan sekolah SMK Negeri 2 Makassar.
\end{abstract}

Kata kunci: kekerasan, siswa SMK, wali siswa

\begin{abstract}
The high school / vocational school situation is following the modern school model in order to adapt its existence to technology era. Synchronization can make more excellence, including in the form of crossborder regional relationships and forming a competitive atmosphere between schools, and build new subsystems to improving the quality of schools, but in fact also poses an additional challenge in running the subsystems within the school, thus requiring a legal approach as a solution to potential conflicts. The method of implementation in this devotion uses a lecture socialization technique in order to create a legal awareness for students, teachers and parents in order to prevent legal problems. Socialization and application of legal symbols for transfer of knowledge to school elements isn't biased after the dedication to the students has been completed.This dedication emphasizes four important points, including: (1) Religious Approach, (2) Student Moral \& Ethics Development, (3) The Importance of Discipline, and (4) Embedding Legal Awareness, which is believed to help keep the school process to its goals any time. Finally, all these important points become the reference for the implementation of concrete activities in the environment of SMK Negeri 2 Makassar.
\end{abstract}

Keywords: violence, vocational students, student trustee

\section{PENDAHULUAN}

Kota Makassar menjadi salah satu target bagi siswa untuk melanjutkan studi bagi masyarakat dikawasan Indonesia bagian timur, karena letak Kota yang cukup sentral 
dan perkembangan ilmu pengetahuan yang cukup dinamis. Perkembangan di Kota Makassar yang demikian pesat ini diikuti dengan perkembangan prilaku siswa, sehingga berbeda prilaku siswa yang ada di Kota yang lebih dinamis perkembangannya dibanding Kota-kota lainnya. Karakteristik tersebut mendorong pemerintah Kota Makassar mencanangkan Visi "Mewujudkan Kota Dunia Untuk Semua, Tata Lorong Bangun Kota Dunia" Sedangkan dan Misi yaitu : "Merekonstruksi nasib rakyat menjadi masyarakat sejahtera standar dunia, Merestorasi tata ruang kota menjadi kota nyaman berkelas dunia, Mereformasi tata pemerintahan menjadi pelayanan publik kelas dunia bebas korupsi."

Perwujudan visi Kota Makassar, merupakan beragam rangkaian aspek yang terangkai dan terbungkus dalam bingkai Misi Kota Makassar. Misi itu kemudian dijabarkan lagi secara luas dalam upaya menciptakan kedisiplinan bagi setiap individu yang terangkum dalam masyarakat Kota Makassar. Dengan peningkatan kedisiplinan pribadi masing-masing individu, maka gerakan untuk menciptakan program Pemerintah Daerah Kota Makassar akan menjadi nyata, karena dengan kedisiplinan akan membawa proses perwujudan visi misi yang bernuansa kearifan lokal itu dapat berjalan dengan lancar, maka diharapkan visi misi itu dapat segera terlaksana sesuai target waktu yang telah ditetapkan sejak awal.

Sebagai satu Kota besar yang ada di Indonesia menjadi ajang untuk mendapatkan berbagai sensasi, namun terkadang sensasi yang ingin dirasakan tersebut tidak didapatkan melalui prestasi-prestasi yang ditorehkan oleh siswa, melainkan sensasisensasi yang dirasakan tersebut dapat berasal dari prilaku positif, dan bahkan prilaku negatif.

Sensasi yang dirasakan dan didapatkan melalui cara-cara yang tidak dibenarkan oleh kaidah yang berlaku dalam masyarakat serta hukum inilah yang kini menjadi fakta riil didalam dunia pendidikan, khususnya siswa SMU dan sederajat. Siswa berlombalomba mencari sensasi dengan lepas kontrol dari ajaran kepatutan, ajaran kesusilaan, bahkan Undang-undang. Pengalaman menjadi pengetahuan siswa didapatkan dari pengamatan yang tidak dikaji secara mendalam, sehingga terkadang sebuah prilaku buruk menjadi acuan bentuk ideal bagi dirinya untuk mendapatkan sensasi dalam sistem pendidikan dan pengajaran di sekolah, dampaknya siswa berasumsi bahwa apa yang dipahaminya adalah suatu kebenaran yang mutlak, sehingga akan diberlakukannya pada lingkungan dimana siswa sekolah.

SMK Negeri 2 Makassar menjadi mitra bagi dosen pengabdi karena citra sekolah yang mulai tercoreng disebabkan oleh prilaku kekerasan yang dilakukan oleh mereka yang berafiliasi dengan lembaga pendidikan tersebut, bahkan telah dipublikasikan oleh berbagai media cetak dan elektronik. Fenomena tersebut disebabkan prilaku agresif salah satu pihak yang merasa tidak terima dengan perlakuan salah satu pihak dalam unsur sekolah, yaitu guru.

Dosen pengabdi mengharapkan ada langkah-langkah yang dapat menetralisir sebuah keadaan yang chaos dalam lingkungan sekolah, agar melalui pengabdian yang dilakukan dosen pengabdi utusan LPMD-UMI dapat dijadikan acuan bagi sekolah lain agar tidak terulang peristiwa serupa. Upaya ini merupakan sebuah pengembangan dari 
metode yang dilaksanakan oleh pihak sekolah yang sebelumnya secara rutin dilaksanakan setiap tahun ajaran yang dilakukan oleh pihak sekolah secara internal. Selain itu, upaya ini juga merupakan pelengkap dari surat edaran Dinas Pendidikan dan Kebudayaan Provinsi Sulawesi Selatan, yang secara implisit dapat dimaknai bahwa pendekatan hukum sejak dini dapat menjadi solusi dalam setiap persoalan kongkrit, bahkan diharapkan agar dapat menghalangi potensi terjadinya permasalahan yang sering menjadi fenomena dalam lingkungan sekolah.

Mengamati publikasi media massa elektronik maupun cetak, sejak akhir 2016 kasus kekerasan yang terjadi dalam lingkungan sekolah hingga hingga kini masih terus terjadi. Meski angka memperlihatkan penurunan, namun potensi peningkatan kasus yang terjadi dalam kurun 2 tahun terakhir masih cukup signifikan. Kekhawatiran timbulnya secara berkelanjutan upaya kriminalisasi dalam perbuatan mendisiplinkan anak sebagai siswa harus segera diredam, berlaku bagi para guru sebagai tenaga pendidik dan pengajar dalam lingkungan sekolah, serta para wali siswa.

Menghadapi persoalan ini, maka pengabdian kepada siswa ini menjadi sebuah pola untuk memutus tindakan kekerasan dalam lingkungan sekolah, khususnya SMK Negeri 2 Makassar. Tema "Desain Penanggulangan Tindakan Kekerasan Oleh Orang Tua Siswa Terhadap Pengajar Dan Pendidik" menjadi acuan kedepannya yang harus diberlakukan pada lingkungan sekolah-sekolah yang ada. Olehnya, penjelasan diatas dapat ditarik sebuah rumusan masalah sebagai berikut:

Tindakan siswa/wali siswa yang sifatnya agresif dalam menanggapi persoalan dengan pihak tenaga pengajar/pendidik yang timbul dalam lingkungan sekolah menjadi sebuah masalah aktual dalam dunia pendidikan. Citra SMK Negeri 2 Makassar telah tercoreng dengan adanya kasus pemukulan yang terjadi dalam lingkungan sekolah. Padahal, berbagai faktor penyebab permasalahan sangat potensial terjadi, olehnya perlu kajian mendalam terlebih dahulu untuk menentukan akar permasalahan. Maka, pengabdian pada siswa ini dilaksanakan untuk menjawab bagaimana cara meminimalisir potensi perselisihan dalam lingkungan SMK Negeri 2 Makassar.

\section{METODE PELAKSANAAN}

Metode pelaksanaan dalam pengabdian ini untuk menggapai tumbuh dan berkembangnnya kesadaran dengan menggunakan teknik ceramah, atau sosialisasi hukum, menggunakan pola deskriptif agar terwujud sebuah bentuk kesadaran hukum bagi siswa. Harapannya tidak terjadi kembali sebuah penilaian yang dapat merusak berbagai unsur yang ada dalam sebuah sekolah, khususnya SMK Negeri 2 Makassar. Selain itu, metode sosialisasi dalam pengabdian berupaya menekankan agar transfer ilmu pengetahuan kepada unsur dalam sekolah tidak bias setelah pengabdian pada siswa telah selesai, dengan cara perumusan kalimat pernyataan yang memotivasi siswa, guru, dan wali siswa dengan nuansa dakwah keagamaan, berkarakter kearifan lokal, lalu dikemas dan disatukan dalam aksesoris sekolah.

Metode konsultasi dijadikan dalam subprogram dari pengabdian ini sebagai bentuk penyempurnaan pengetahuan kepada seluruh pihak terkait agar transfer iptek diharapkan dapat mencapai seluruh target yang ingin dicapai secara merata, dengan 
membuka waktu dan ruang dalam lingkungan sekolah kapan pun selama masa pengabdian dijalankan oleh para dosen pengabdi, dan dijadikan sebagai bahan observasi untuk memberikan penilaian terhadap program yang dijalankan, yang kemudian dapat menjadi salah satu ukuran dan pertimbangan bahwa program telah berjalan sesuai dengan target yang direncanakan.

\section{HASIL DAN PEMBAHASAN}

Persoalan dalam lingkungan sekolah terus meningkat, namun masih menyisakan berbagai persoalan dimasa lampau. Kekerasan diberbagai sekolah SMU dan sederajat terjadi dimana-mana, bahkan hingga saling memidanakan terus terjadi akibat pemicunya tak kunjung hilang. Keadaan anomali sudah masuk dalam lingkungan sekolah, padahal salah satu tujuan ruang pendidikan diadakan yaitu tempat proses belajar mengajar untuk menemukan/pemecahan berbagai solusi dari berbagai hambatan yang dapat timbul dikemudian hari melalui pengetahuan yang dimiliki manusia, dan tertuang dalam peraturan perundang-undangan Indonesia Pasal 3 UU Nomor 20 Tahun 2003 tentang Sistem Pendidikan nasional, meyatakan: pendidikan nasional adalah mengembangkan potensi peserta didik agar menjadi manusia yang beriman dan bertakwa kepada Tuhan yang Maha Esa, berakhlak mulia, sehat berilmu, cakap, kreatif, mandiri, dan menjadi warga negara yang demokratis serta bertanggung jawab.

Dalam sebuah perspektif, beberapa tindakan dalam lingkungan sekolah itu bisa berpotensi sebagai sebuah kekerasan, namun hal tersebut harus disandarkan terlebih dahulu pada motivasi seseorang melakukan sebuah tindakan, tindakan yang dimaksud baik itu represif, maupun responsif. Upaya dalam menanggulangi tindakan kekerasan dalam lingkungan sekolah melalui sosialisasi tentang pentingnya kesadaran hukum tersebut diadakan agar tidak memberi kesan terjadinya tindak kekerasan pada siswa yang dilakukan oleh para guru sebagai orang tua dalam lingkungan sekolah, yang dapat memberi dampak wali siswa melakukan tindakan balasan kepada guru. Asumsi bagi guru sebagai orang tua dalam lingkungan sekolah adalah, if the position is not in place anymore, and an authority has been misused, then the peace of life has been disrupted and propriety have been threatened, maka dalam perwujudannya dilaksanakan beberapa program oleh para dosen pengabdi, diantaranya:

\section{Pendekatan Keagamaan}

Pemanfaatan sarana ibadah dalam lingkungan sekolah adalah salah satu program kongkrit yang dilaksanakan dalam kegiatan pengabdian ini. Pemanfaatan sarana ibadah ini bertujuan meningkatkan pendekatan keagamaan bagi siswa yang dapat memanfaatkan sarana ibadah yang telah tersedia, termasuk pemeliharaan sarana sekolah yang dapat mengembangkan sikap disiplin siswa, juga pemeliharaan iklim berKetuhanan yang Maha Esa, karena nilai religi adalah faktor penting untuk dijadikan sebuah pertimbangan bagi siswa dalam memutuskan sebuah tindakan.

Kegiatan sosialisasi ditahap awal dengan pendekatan keagamaan akan membuka pintu penerimaan segala hal baik dalam diri siswa, agar secara efisien ketika hukum disisipkan kedalam jiwa siswa sebagai pembentuk nilai moral yang baik. Pembinaan 
anak dalam beribadah dianggap sebagai penyempurna dari pembinaan aqidah karena nilai ibadah yang didapat oleh anak akan dapat menambah keyakinan akan kebenaran ajarannya atau dalam istilah lain, semakin tinggi nilai ibadah yang ia miliki, akan semakin tinggi pula nilai keimanannya. Melatih siswa dengan membentuk kebiasaan dapat menjadikan kebenaran ajaran yang diyakini siswa akan secara konkrit terwujud dalam prilakunya didalam maupun diluar lingkungan sekolah.

Pendekatan keagamaan sejak dini yang dimaksud dalam ajaran agama islam bukanlah sejak siswa duduk dalam bangku SMU dan sederajat, bahkan jauh sebelumnya pada umur 8 Tahun sudah diwajibkan untuk mulai menjalankan ibadah. Kewajiban yang diemban seorang anak sejak umur 8 tahun sesungguhnya bukanlah sebuah beban yang dapat membuat siswa mendapatkan tekanan, namun harapannya lebih kearah persiapan, latihan dan pembiasaan, karena tekanan yang dialami siswa bisa berpengaruh pada motivasi untuk berprestasi.Harapan kepada siswa untuk tumbuh dan berkembang sesuai dengan agama yang dianutnya tentu dapat diwujudkan karena hukum yang diberlakukan kepada anak selalu mengacu pada kerangka dasar dari terbentuknya UU No. 35 Tahun 2014 tentang Perlindungan Anak.

Pembentukan kecerdasan emosional siswa dapat ditemukan melalui pendekatan keagamaan ini, siswa yang telah terlatih akan lebih sabar menghadapi persoalan yang terjadi dalam lingkungan sekolah, baik itu kepada temannya para siswa, maupun kepada guru sebagai orang tua dalam sekolah. Memiliki kecerdasan emosional yang tinggi bagi siswa merupakan bagian dari tujuan adanya lingkungan pendidikan, academic success was strongly associated with several dimensions of emotional intelligence (intrapersonal, adaptability, and stress management abilities) assessed at the start of the academic year.[8] Melalui pendekatan ini maka akan meningkatkan potensi dan membuka peluang pada siswa akan lanjut pada tingkat pendidikan lebih tinggi, dan hal tersebut mengisyaratkan bahwa akan memberikan opsi tambahan bagi tujuan siswa bersekolah di SMK Negeri 2 Makassar, bukan hanya sebagai calon lulusan yang siap bekerja tetapi juga jenjang SMK mampu mempersiapkan sumber daya manusia mengisi bangku kuliah pada universitas.

\section{Program Pembinaan Moral dan Etika}

Pentingnya pendekatan moral dan etika bagi siswa karena masih banyak siswa yang belum memahami tentang pentingnya menjaga moral, sehingga mereka masih terkesan acuh dan hanya sekedar melalui proses pendidikan di sekolah dengan harapan mendapatkan ijazah untuk dijadikan prasyarat dalam memenuhi berbagai kebutuhan dikemudian hari. Ironisnya jika mereka sebagai penerus dan penjaga peradaban manusia dimasa akan datang mengabaikan peran pentingnya moral dalam mengambil sebuah tindakan, misalnya mengabaikan prinsip kepatutan, kesusilaan dan bahkan perundang-undangan yang berlaku.

Informasi yang terpublikasi dalam berbagai bentuk media informasi telah menunjukkan dewasa ini telah terjadi degradasi moral manusia. Khususnya pada siswa SMK Negeri 2 Makassar (teknologi dan industri) bahwa dengan pendidikan dalam menggapai ilmu pengetahuan yang akan diterapkan kepada manusia lain yang membutuhkan dan menerapkan, dipandang perlu menerapkan moral dengan 
menyandarkan diri pada nilai-nilai religi pada setiap tindakan dan menjauhkan diri dari orientasi uang semata, demoralization-the process of society's progressive loss of or weakening of the moral and ethical structures that have traditionally prevailed, karena dalam perkembangan dunia teknologi industri yang sangat mengesankan dewasa ini merupakan pengembangan ilmu pengetahuan dan juga mengikut sarana efektif untuk melakukan perbuatan melawan hukum.

Kegiatan pembekalan bagi siswa yang akan berangkat praktek kerja industri kedepannya merupakan kegiatan rutin yang dilakukan oleh siswa SMK Negeri 2 Makassar sebagai bekal menjaga prilaku siswa pada tempat prakteknya, berangkat dari nilai moralitas yang terjaga dengan menyandarkan diri pada nilai-nilai religinya sehingga etika dalam praktek kerja industrinya dapat terlaksana dan berjalan kearah tujuan yang diharapkan sebagai luaran dari praktek tersebut. Siswa harus mendapatkan pengalaman maksimal dari tugas yang diembankan kepadanya, maka perlu merekonstruksi kembali pola dalam upaya menggapai keseriusan siswa dalam praktik, sehingga luaran yang dihasilkannya betul-betul menjadi manusia berdaya saing tinggi bagi bangsa.

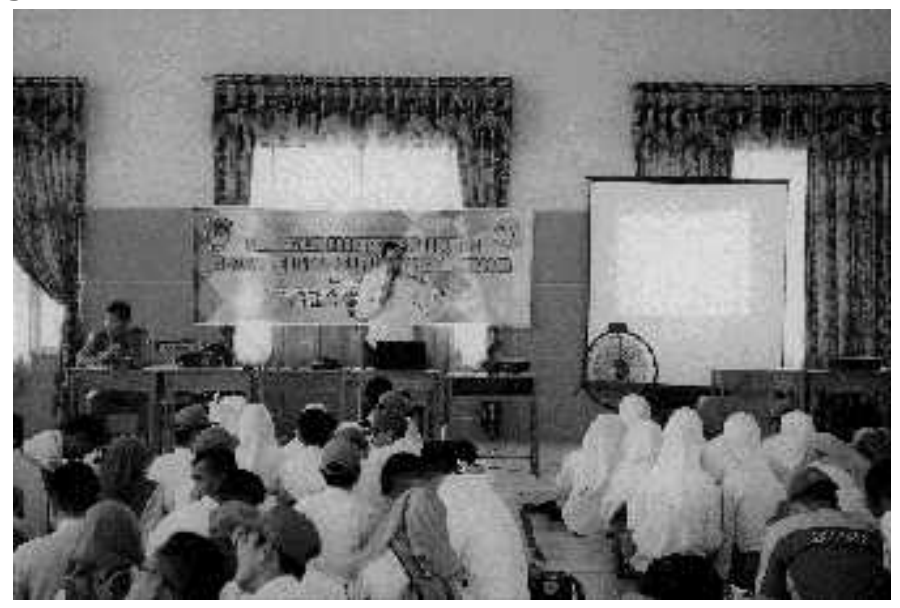

\section{Gambar. 1}

Sosialisasi Urgensi Kesadaran Hukum: Pengembangan Etika \& Moral dalam Teknologi Industri di SMK Negeri 2 Makassar.

Pembinaan moral dan etika dalam lingkungan sekolah perlu dirasakan peningkatannya, agar tindakan perbuatan melanggar hukum dalam lingkungan sekolah dapat diminimalisir secara bertahap. Efek dari moral dan etika yang berkembang melalui dunia pendidikan ini harus terasa dampaknya hingga kepada orang tua wali siswa, agar benar-benar dapat menaruh kepercayaan publik dalam dunia pendidikan.Siswa berprestasi merupakan capaian yang diharapkan oleh para orang tua (baik guru maupun wali), maka dalam menuju mencapai sebuah prestasinya siswa cukup disibukkan dan bagi siapa saja akan merasakan siswa terkesan aktif belajar dan prilaku membuang-buang waktunya mulai berkurang. Kesan positif akan menepis isu negatif yang timbul sehingga isu kekerasan yang terjadi dalam lingkungan sekolah pun dapat diminimalisir.

Siswa yang mengalami peningkatan pemahaman tentang pentingnya ilmu mereka ditengah masyarakat akan segera tersadar dan semakin bersemangat belajar, 
serta dapat membawa prilaku positif tersebut kepada siswa lainnya. Sensasi positif dapat ditemukan siswa pada dunia teknologi dan industri, dampaknya para siswa yang akan mengikuti Praktek Kerja Industri akan menjadi lebih bersemangat berangkat pergi praktek. Moral idealnya dapat merefleksi kritis persoalan berhukum yang tidak terjawab oleh hukum moderen, untuk inilah kajian moral menjadi wacana penting berhukum kita bukan basa-basi lagi, secara sejak dini diperkenalkan ilmu hukum kepada siswa.

\section{Program Penciptaan Kedisiplinan di Sekolah}

Kedisiplinan dalam lingkungan sekolah harus bertumbuh, bukan karena maraknya kriminalisasi terhadap tenaga pengajar dan pendidik disekolah dapat menjadi acuan menurunkan tingkat kedisiplinan tersebut menurun melalui kebenaran pragmatis, namun sebaliknya dalam rangka penegakan kedisiplinan guru berhak mendapatkan perlindungan dalam melaksanakan tugas, sebagaimana dinyatakan dalam Pasal 40 Peraturan Pemerintah Nomor 74 Tahun 2008 Tentang Guru.

Dewasa ini seringkali ketika masuk kedalam lingkungan sekolah, kedisiplinan dalam lingkungan sekolah masih dalam tahap rendah, misalnya dalam praktik olah raga masih tak beraturan, terlihat ada yang, aktif, ada bermain, bahkan ada sekedar duduk, sedangkan pengembangan potensi peserta didik sebagai manusia yang sehat juga tertuang dalam Pasal 3 UU no 20 /2003 tentang Sistem Pendidikan Nasional. Sesungguhnya, disiplin bukan merupakan sikap mental yang dibawa sejak lahir, tetapi banyak dipengaruhi oleh pengalaman sekitar khususnya pengalaman pendidikan, dan mendisiplinkan siswa dengan cara bertindak sesuai batasan kewenangan bukanlah sebuah perbuatan melawan hukum (onrechmatige daad).

Kedisiplinan dapat dibina untuk dikembangkan dalam berbagai bidang, termasuk juga olah raga. Contohnya dalam lingkungan sekolah, kedisiplinan terbentuk dari giat belajar untuk menjadikan siswa cerdas dan berprestasi di bidang ilmu pengetahuan, ada disiplin olah raga untuk menjadikan siswa juara dan berprestasi dibidang olah raga. Kedisiplinan dalam berbagai bidang dapat meminimalisir berbagai tindakan atau perbuatan melawan hukum, misalnya buli, penganiayaan, dan kekerasan. Setiap siswa, yang berprestasi dalam setiap bidang yang dikuasainya wajib diberikan apresiasi dari seluruh pihak, dalam arti menjunjung tinggi hak asasi manusia pada siswa yang secara implisit terkandung dalam pernyataan UUD 1945 Pasal 29C ayat (1), karena itu akan membangun kemauan dan mengembangkan kreativitas siswa dalam proses pembelajaran.

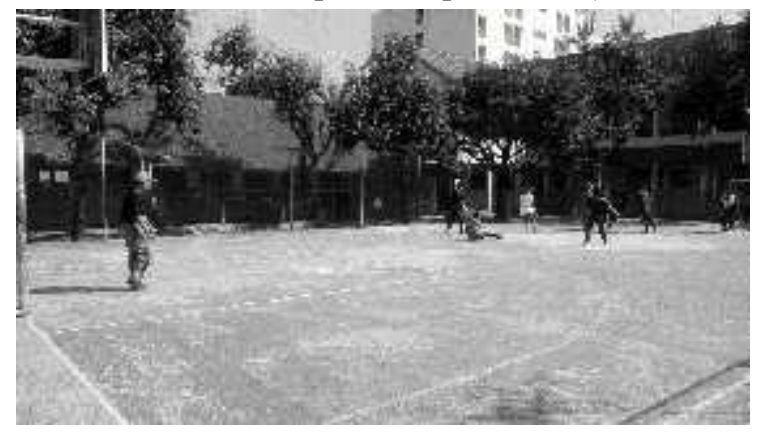




\section{Gambar. 2}

Suasana Praktik Olah Raga Futsal di SMKN 2 Makassar

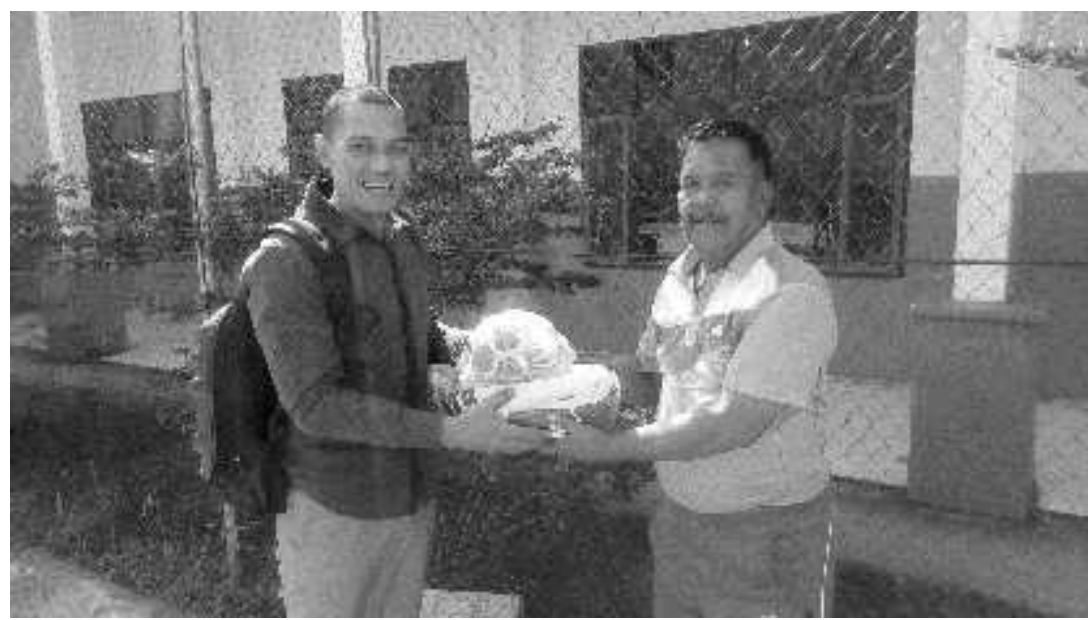

Gambar.3

Menambah motivasi raihan prestasi olah raga futsal dengan menambah prasarana olah raga.

Setelah menyediakan beberapa prasarana yang dibutuhkan untuk berolah raga, jadwal olah raga disekolah mulai berjalan dengan baik, para guru yang bertugas ikut mengembangkan strategi berolah raga secara profesional yaitu penerapan strategi, bahkan tambahan jam ekstrakurikuler pada sore hari. Promosi kesehatan dapat diberikan melalui media sehingga pesan yang disampaikan dapat diterima serta dipahami oleh target dan target dapat berperilaku positif,[14] media tersebut dapat berupa prasarana olahraga, contohnya pada Gambar 3. Dampaknya adalah yang aktif berolahraga semakin banyak, yang bermain dan duduk semakin berkurang, antusias siswa ingin menunjukkan prestasi mereka dalam olahraga sebagai sebuah sensasi positif bagi siswa yang harus terus dijaga.

Dorongan membentuk dan mengembangkan kedisiplinan secara berkesinambungan seharusnya bukan tugas guru semata, namun siswa pun harus tahu terlebih dahulu tentang pentingnya ilmu pengetahuan baginya melalui pemahaman dari peran serta berbagai pihak terkait, sehingga mereka semangat belajar atau giat berlatih. Hal lain adalah terkait dengan kurangnya suasana kompetisi di sekolah sendiri yang lebih menekankan pada penguasaan kemampuan praktek pada siswanya.[7]

\section{SIMPULAN}

Sistem ini merupakan sebuah acuan untuk terus digalakkan dalam lingkungan sekolah, khususnya SMK Negeri 2 Makassar, siswa dan wali siswa mulai menyadari bahwa motivasi tindakan mendisiplinkan siswa semata karena kebaikan, hanya karena kewenangannya dan bukan niat untuk melakukan kekerasan atau penganiayaan. Efek peningkatan sikap yang bernuansa religi, peningkatan moral dan etika dalam dunia pendidikan harus dapat dirasakan oleh orang tua wali dan guru, agar kepercayaan 
publik terhadap lingkungan sekolah meningkat, sehingga isu negatif pun dapat ditepis. Pengembangan kedisiplinan siswa dapat diperoleh dari berbagai bidang kegiatan disekolah, melalui sikap apresiatif yang diberikan oleh guru, dan wali siswa, sehingga dengan berbagai raihan prestasi siswa akan meminimalisir kriminalisasi dalam lingkungan pendidikan.

\section{DAFTAR RUJUKAN}

Makassarkota.go.id, "Walikota Makassar - Ramdhan Pumanto," 2013. [Online]. Available: http://www.makassarkota.go.id/profilpimpinan.html. [Accessed: 17-Mar-2017].

Makassarkota.go.id, "Walikota Makassar - Ramdhan Pumanto," 2013. [Online]. Available: http://www.makassarkota.go.id/profilpimpinan.html. [Accessed: 17-Mar-2017].

Kompas.com, “Orangtua dan Murid yang Pukul Guru di Makassar Jadi Tersangka,” 2016. [Online]. Available: http://regional.kompas.com/read/2016/08/11/10493651/orangtua.dan.murid.y ang.pukul.guru.di.makassar.jadi.tersangka. [Accessed: 21-May-2017].

Kompas.com, "Kata JK tentang Pemukulan Guru di Makassar," 2016. [Online]. Available: http://nasional.kompas.com/read/2016/08/12/22521281/kata.jk.tentang.phttp: //nasional.kompas.com/read/2016/08/12/22521281/kata.jk.tentang.pemukula n.guru.di.makassaremukulan.guru.di.makassar. [Accessed: 22-May-2017].

Kpai.go.id, "Selama 2016, KPAI Catat 1000 Kasus Kekerasan pada Anak," 2016. [Online]. Available: http://www.kpai.go.id/berita/8194/. [Accessed: 10-Aug-2017].

A. A. Nurul Qamar, Hikmawati Mustamin, "Local Wisdom Culture of Bugis-Makassar in Legal Perspective," ADRI Int. J. Law Soc. Sci., vol. 1, no. 1, pp. 31-36, 2017.

K. Maksum, “Konsep Dasar Pembinaan Kesadaran Beragama Dalam Dunia Pendidikan Anak," J. Literasi (Jurnal Ilmu pendidikan), vol. 3, no. 1, pp. 31-42, 2012.

N. Apranadyanti, "Hubungan Antara Regulasi Dini Dengan Motivasi Berprestasi Pada Siswa Kelas X SMK Ibu Kartini Semarang,” Semarang, 2010.

J. D. A. Parker, L. J. Summerfeldt, M. J. Hogan, and S. A. Majeski, "Emotional intelligence and academic success: Examining the transition from high school to university," Pers. Individ. Dif., vol. 36, no. 1, pp. 163-172, 2004.

Q. Zheng, Y. Luo, and S. L. Wang, "Moral Degradation, Business Ethics, and Corporate Social Responsibility in a Transitional Economy," J. Bus. Ethics, vol. 120, no. 3, pp. 405-421, 2014.

S. Haryadi, "Moral Dalam Lintasan Filsafat Dan Teori." [Online]. Available: 
https://www.academia.edu/5292089/MORAL_DALAM_LINTASAN_FILSAFAT_DA N_TEORI_HUKUM. [Accessed: 17-Jul-2017].

Sang Pencerah, "Guru Agama di Parepare Dipidana, Karena Perintahkan Shalat." [Online]. Available: http://sangpencerah.id/2017/07/guru-agama-di-pareparedipidana-karena-perintahkan-shalat/. [Accessed: 06-Aug-2017].

H. Rohmansyah, "Implementasi Gaya Mengajar Resiprokal Dalam Aktivitas Pembelajaran Pencak Silat Untuk Mengembangkan Sikap Disiplin Siswa | repository.upi.edu | perpustakaan.upi.edu," Universitas Pendidikan Indonesia, 2014.

Mahkamah Agung RI, Putusan MAHKAMAH AGUNG RI Nomor 1554 K/PID/2013 Tahun 2014. Republik Indonesia, 2014.

M. A. Alfarizki, M. Purwoko, and R. Pratiwi, "Upaya Peningkatan Tingkat Pengetahuan Siswi MAN 2 Palembang Mengenai Sindrom Pramenstruasi," Indones. J. Community Engagem. JPKM-UGM, vol. 2, no. 2, pp. 235-245, 2017. 